\title{
Dependence of Initial Oxygen Concentration on Ozone Yield Using Inductive Energy Storage System Pulsed Power Generator
}

\author{
Tomio Go Member (Ichinoseki National College of Technology) \\ Yasushi Tanaka Non-member (Iwate University) \\ Nobuyuki Yamazaki Student Member (Iwate University) \\ Seiji Mukaigawa Member (Iwate University) \\ Koichi Takaki Member (Iwate University) \\ Tamiya Fujiwara Member (Iwate University)
}

Keywords : pulsed power, inductive energy storage, semiconductor opening switch diodes, ozone generation, ozone yield, oxide concentration

Dependence of initial oxygen concentration on ozone yield using streamer discharge reactor driven by an inductive energy storage system pulsed power generator is described in this paper. Fast recovery type diodes were employed as semiconductor opening switch (SOS) to interrupt a circuit current within $100 \mathrm{~ns}$. This rapid current change produced high-voltage short pulse between a secondary energy storage inductor. The repetitive high-voltage short pulse was applied to wire electrode placed in the center of a cylindrical pulse corona reactor. Figure 1 shows experimental setup for ozone generation.

The experimental result showed that the width of the output pulse voltage at no-load condition was measured to be in range from 20 to $70 \mathrm{~ns}$ of full-width half-maximum. The streamer discharge successfully occurred between a $1 \mathrm{~mm}$ diameter center wire electrode and an outer cylinder ground electrode of $2 \mathrm{~cm}$ inner diameter. The ozone was produced with the streamer discharge and increased with increasing pulse repetition rate.

Figure 2 shows the energy transfer from primary energy storage capacitor to discharge and energy consumed in the reactor $E_{\text {load }}$ and in the $\operatorname{SOS} E_{\mathrm{SOS}}$ at $C=4 \mathrm{nF}$ (primary energy storage capacitor), $L=12.6 \mu \mathrm{H}$ (secondary energy storage inductor) and $V_{\mathrm{C} 0}=-12 \mathrm{kV}$. The energy transfer from the primary energy storage capacitor to the reactor is around $23 \%$ under this condition.

Figure 3 shows the ozone yield for conditions (1) $C=1.35 \mathrm{nF}$ $L=1.4 \mu \mathrm{H}$ (forward pumping time is about $180 \mathrm{~ns}$ ) and (3) 4 $\mathrm{nF}-12.6 \mu \mathrm{H}$ (forward pumping time is about $800 \mathrm{~ns}$ ). The ozone yield changed in proportion to initial oxygen concentration contained in the injected gas mixture at $800 \mathrm{~ns}$ forward pumping time of the circuit current. However, the decrease of the ozone

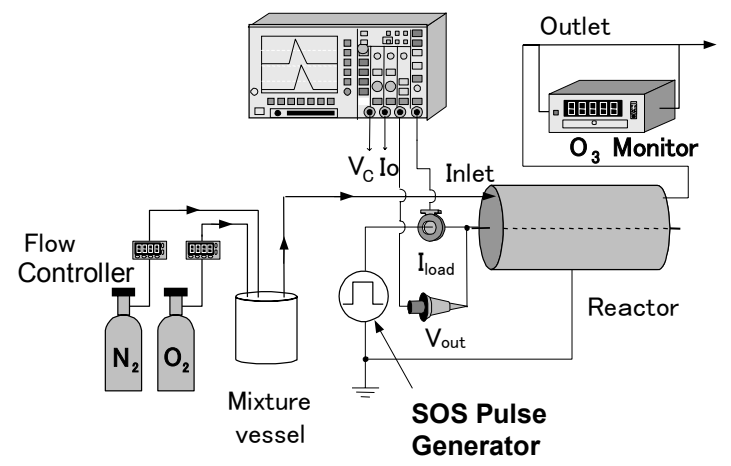

Fig. 1. Experimental setup for ozone generation yield by decreasing oxygen concentration in the gas mixture at $180 \mathrm{~ns}$ forward pumping time was lower than the decrease at 800 ns forward pumping time. This dependence of the initial oxygen concentration on ozone yield at $180 \mathrm{~ns}$ forward pumping time is similar to that of dielectric barrier discharge (DBD) reactor.

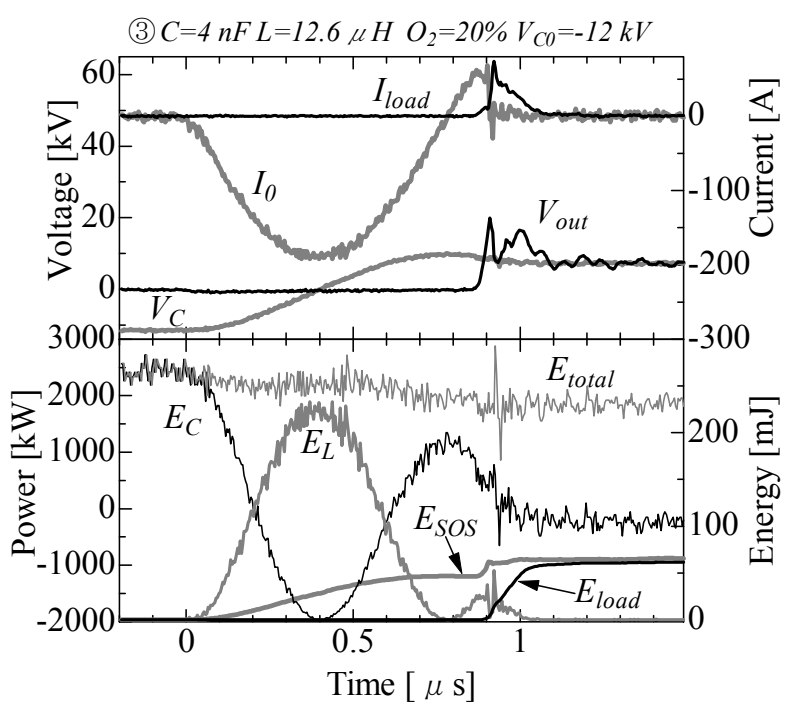

Fig. 2. Energy transfer from primary energy storage capacitor to discharge at $C=4 \mathrm{nF}, L=12.6 \mu \mathrm{H}$ and $V_{\mathrm{C} 0}=-12 \mathrm{kV}$

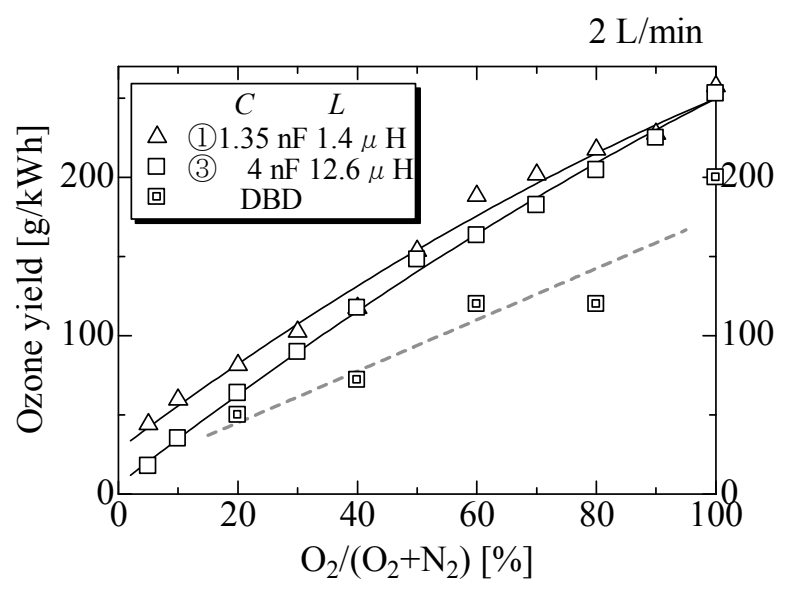

Fig. 3. Ozone yield as a function of ozone concentration for conditions (1),(3) and DBD 
䜊 文

\title{
誘導性パルスパワー電源を用いたオゾン生成の酸素濃度依存性
}

$\begin{array}{llllll}\text { 正員 郷 } & \text { 冨夫* } & \text { 非会員 } & \text { 田仲 } & \text { 泰** } \\ \text { 学生員 山崎 } & \text { 信幸** } & \text { 正 員 } & \text { 向川 } & \text { 政治** } \\ \text { 正 員 高木 } & \text { 浩一** } & \text { 正 員 } & \text { 藤原 } & \text { 民也** }\end{array}$

\section{Dependence of Initial Oxygen Concentration on Ozone Yield Using Inductive Energy Storage System Pulsed Power Generator}

Tomio Go*, Member, Yasushi Tanaka**, Non-member, Nobuyuki Yamazaki**, Student Member, Seiji Mukaigawa**, Member, Koichi Takaki**, Member, Tamiya Fujiwara**, Member

\begin{abstract}
Dependence of initial oxygen concentration on ozone yield using streamer discharge reactor driven by an inductive energy storage system pulsed power generator is described in this paper. Fast recovery type diodes were employed as semiconductor opening switch to interrupt a circuit current within $100 \mathrm{~ns}$. This rapid current change produced high-voltage short pulse between a secondary energy storage inductor. The repetitive high-voltage short pulse was applied to a $1 \mathrm{~mm}$ diameter center wire electrode placed in a cylindrical pulse corona reactor. The streamer discharge successfully occurred between the center wire electrode and an outer cylinder ground electrode of $2 \mathrm{~cm}$ inner diameter. The ozone was produced with the streamer discharge and increased with increasing pulse repetition rate. The ozone yield changed in proportion to initial oxygen concentration contained in the injected gas mixture at $800 \mathrm{~ns}$ forward pumping time of the current. However, the decrease of the ozone yield by decreasing oxygen concentration in the gas mixture at $180 \mathrm{~ns}$ forward pumping time of the current was lower than the decrease at $800 \mathrm{~ns}$ forward pumping time of the current. This dependence of the initial oxygen concentration on ozone yield at $180 \mathrm{~ns}$ forward pumping time is similar to that of dielectric barrier discharge reactor.
\end{abstract}

キーワード : パルスパワー, 誘導性エネルギー蓄積, SOS ダイオード, オゾン生成, オゾン生成効率, 酸素濃度

Keywords : pulsed power, inductive energy storage, semiconductor opening switch diodes, ozone generation, ozone yield, oxide concentration

\section{1. はじめに}

オゾンは酸素原子のみで構成され，自然界ではフッ素に 次ぐ強力な酸化力を有し, 殺菌, 酸化, 漂白, 脱色, 脱臭 などに広く用いられている(1)。オゾンの発生方式には, 放電 方式, 紫外線照射方式, 水の電気分解による方式などがあ る。放電方式は，装置が簡便になる，エネルギー効率がよ いなどの利点を有しており，このため，数多くの製品が開 発され，広く利用されている。放電方式では，一般に，誘 電体バリア放電 ${ }^{(2)}$ や, 沿面放電, 誘電体充填放電 ${ }^{(3)}$ な゙゙が用 いられている。これらの方式は, 比較的大量のオゾン生成 が可能であるという特徵がある。しかしながら, オゾンの

\footnotetext{
* 一関工業高等専門学校

T021-8511 一関市萩荘字高梨

Ichinoseki National College of Technology

1-1-1, Takanashi, Hagisho, Ichinoseki 021-8511

** 岩手大学工学部

T020-8551 盛岡市上田 4-3-5

Iwate University

4-3-5, Ueda, Morioka 020-8551
}

生成効率が低いなど，解決すべき問題も残されている。パ ルスパワーを利用してストリーマ放電を発生させるパルス ストリーマ方式でのオゾン生成は, 誘電体バリア放電方式 と比較して換算電界強度が高いためにオゾン生成効率の向 上が期待できる(4)ことから, 国内外で盛んに研究がなされて いる(5) (7)。しかしパルス電源のエネルギー効率の改善や電 源のコンパクト化など, 課題も残されている。

本研究では, パルスストリーマ方式により, 高いオゾン 生成効率をコンパクトな装置で実現することを目的として いる。パルスパワー発生方式には投入スイッチを使用して コンデンサに蓄えたエネルギーを負荷に転送する容量性エ ネルギー蓄積方式と, 開放スイッチを使用してインダクタ に流れる電流を遮断して負荷にエネルギーを転送する誘導 性エネルギー蓄積方式がある。エネルギー蓄積密度が大き い後者の方が, 装置の小型化に対して有利である。誘導性 エネルギー蓄積方式で必要となるインダクタに流れる大電 流を高速で遮断する開放スイッチは, 今まで小型のものが なかった。しかし, 近年, ロシアで半導体開放スイッチ 
(Semiconductor Opening Switch Diode : SOS ダイオード) が 開発された ${ }^{(8)}$ 。この半導体開放スイッチは，電流が順方向か ら逆方向に反転する際すぐには遮断せず，適当な時間（自 己回復時間）を経たあとに遮断されるという特徴を有する。 半導体開放スイッチは，半導体デバイスであることから， 動作が安定, 寿命も半永久的であるという特徵があり, こ こで述べるオゾン生成に適用されるほか，排ガス処理など 小型で優れた開放スイッチとしての応用研究が進められて いる(9)(10)。また, パルスパワー電源自体として, 高出力化, 高効率化, 小型化, 高繰り返し化などの研究も精力的にな されている(11)(12)。

ここでは, 誘導性エネルギー蓄積方式のパルスパワー電 源を用い，オゾン生成効率の酸素濃度依存性について調べ た結果について述べる。

\section{2. 実験概要}

〈2・1〉 パルスパワー電源実験回路を図 1 に示す。 パルス発生回路は, コンデンサ $\mathrm{C}$, 自爆型のギャップスイ ッチ GS, インダクタ L, 半導体開放スイッチ SOS, 高電圧 直流電源（図中 D.C.H.V と表記）より構成される。コンデ ンサCに電荷を蓄積するために高電圧直流電源（パルス電 子製直流電源 $\mathrm{HDV}-50 \mathrm{~K} 125 \mathrm{X}$ (DC-50kV，12mA））を用い, 半導体開放スイッチとしては, VOLTAGE MULTIPLIERS 社 の高速スイッチングダイオード K100UF（定格 $10 \mathrm{kV} / 100 \mathrm{~A}$ ） を 5 直列 $\times 4$ 並列接続して使用した。

回路動作は以下のようになる。コンデンサ C が充電され ると, ギャップスイッチ GS が放電し，LC 振動回路により 半導体開放スイッチ SOS に順方向電流が流れ, 空乏層に電 荷を蓄積する。続く極性反転に際し，蓄積した電荷は逆方 向電流となって流れ続けるが，ある時間を経て空乏層の蓄 積電荷が消滅したときに急激な電流遮断が起こり，インダ クタ Lの作用により半導体開放スイッチ両端にパルス電圧 が発生する。半導体開放スイッチを流れる電流はロゴスキ ーコイル（Pearson Current monitor Model 2878）を用い，ま た出力電圧は高圧プローブ（Sony Tektronix P6015A）を用い て計測し，デジタルオシロスコープ（Sony Tektronics TDS3054B）に記録した。

〈2·2〉 オゾン生成装置図 2 にオゾン生成実験装置 の構成図を示す。酸素と窒素の混合ガスを原料として使用 し, ガス流量は $2 \mathrm{~L} / \mathrm{min}$ とした。ガスは, デジタルマスフロ ーコントローラー（株式会社山武社製 CMQ0005）を用い流 量を制御した。オゾン濃度は，オゾンメータ（荏原実業株 式会社製 $\mathrm{EG}$-2001B）を用いて測定した。リアクタは，同 心円筒形状をしており, 直径 $1 \mathrm{~mm}$ のタングステン線と, 内 径 $20 \mathrm{~mm}$ ，長さ $300 \mathrm{~mm}$ の銅管で構成されている。

〈2·3〉 オゾン生成実験条件 図 2 のオゾン生成実験 装置に図 1 のパルスパワー電源を接続して, オゾン生成濃 度の測定を行った。表 1 に, 電源を構成する回路パラメー タであるコンデンサの容量 $C$, インダクタのインダクタンス $L$, および無負荷時の特性として出力電圧 $V_{\text {out } 0}$, 半導体開

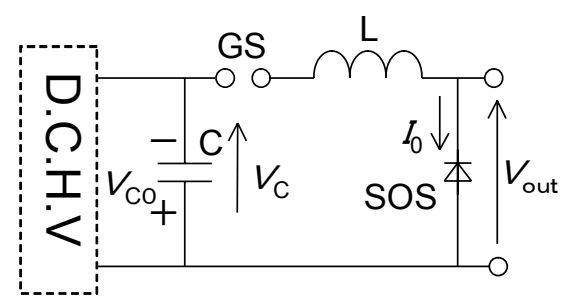

図 1 パルスパワー電源回路

Fig. 1. Pulsed Power Generator circuit.

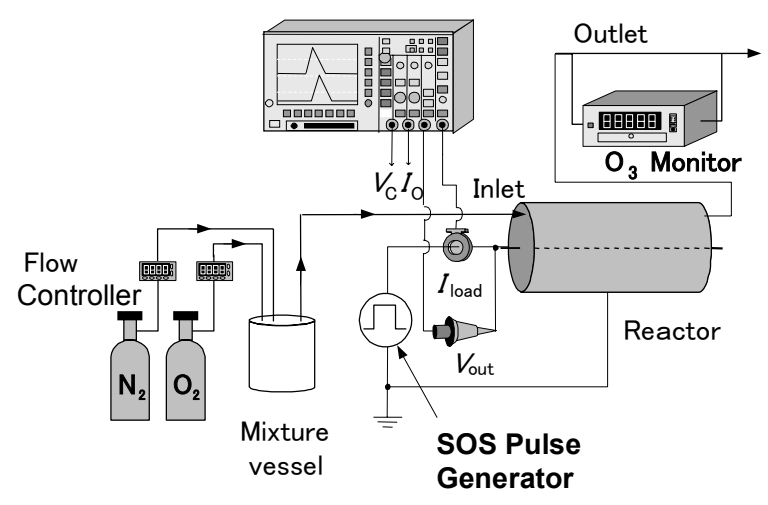

図 2 オゾン生成実験装置

Fig. 2. Experimental setup for ozone generation.

表 1 オゾン生成実験の回路パラメータ

Table 1. Circuit conditions employed in the experiment.

\begin{tabular}{|l|l|l|l|l|l|}
\hline & $C[\mathrm{nF}]$ & $L[\mu \mathrm{H}]$ & $V_{\mathrm{C}_{0}}[\mathrm{kV}]$ & $V_{\text {out } 0}[\mathrm{kV}]$ & $t_{\mathrm{f}}[\mathrm{ns}]$ \\
\hline$(1)$ & 1.35 & 1.4 & -14 & 31 & 180 \\
\hline$(2)$ & 2.7 & 0.7 & -14 & 25 & 220 \\
\hline$(3)$ & 4 & 12.6 & -12 & 35 & 800 \\
\hline$(4)$ & 10.7 & 8.1 & -12 & 35 & 1000 \\
\hline
\end{tabular}

放スイッチ SOS に流れる電流の順方向励起時間 $t_{\mathrm{f}}$ を示す。 パルス電圧をリアクタに加えると, リアクタ内部の電界で 電子が加速され電子なだれが生じ, ストリーマ放電が進展 する。一般に, ストリーマ放電の先端付近の電子エネルギ 一は $10 \mathrm{eV}$ 程度 ${ }^{(13)}$ と高く, オゾン生成に必要な酸素分子の 解離などを引き起こすことができる。コンデンサ容量 $C$ が 大きくなり順方向励起時間 $t_{\mathrm{f}}$ が長くなるとパルス電圧の継 続時間も長くなり，放電は容易にアーク放電に至る ${ }^{(14)}$ 。ア 一ク放電中の電子エネルギーは $1 \mathrm{eV}$ 程度で低く ${ }^{(15)}$, 酸素分 子解離などに寄与することができない。このため, 表 1 に 示すコンデンサ充電電圧 $V_{\mathrm{C} 0}$ (マイナス充電) は, アーク放 電が発生しない值に設定した。

\section{3. 実験結果と検討}

〈3·1〉電源の特性 図 3 に, 表 1 の回路パラメータ を含めた代表的なインダクタンス $L$ に対する無負荷での出 カパルスの電圧幅 (半值幅) を示す。図 3 より, パルス電 圧の半值幅は, インダクタンス $L$ とキャパシタンス $C$ を乗 じた值 $L C$ に強く依存していることがわかる。例として, 表 1 


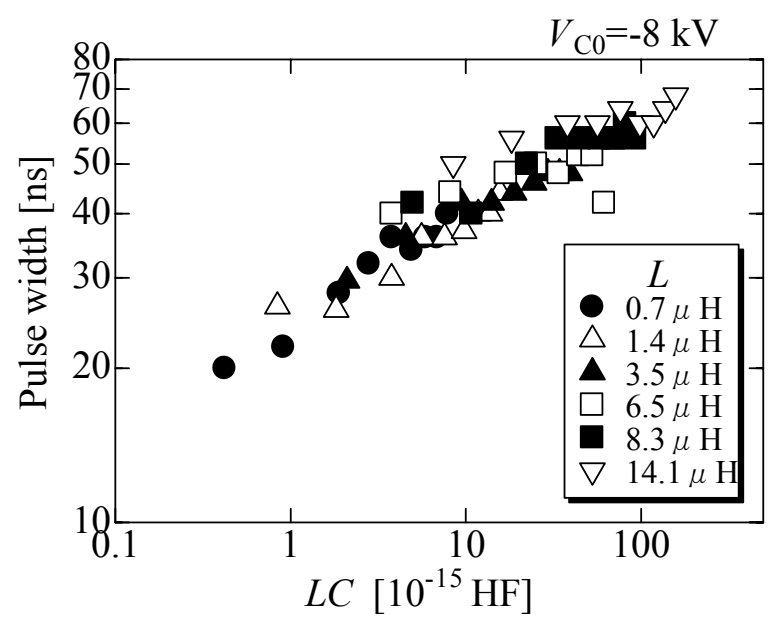

図 3 無負荷での発生パルス電圧の半值幅

Fig. 3. Pulse width of the no-load output voltage as a function of multiplication $L \times C$.

の条件(1) $C=1.35 \mathrm{nF}, L=1.4 \mu \mathrm{H}$ で $L C=1.82 \times 10^{-15}[\mathrm{HF}]$ のとき のパルス電圧の半值幅は約 $25 \mathrm{~ns}$, 条件(3) $C=4 \mathrm{nF}, L=12.6 \mu \mathrm{H}$ で $L C=50.4 \times 10^{-15}[\mathrm{HF}]$ のときのパルス電圧の半值幅は約 60 ns となる。この無負荷でのパルスの電圧幅は, 負荷インピ ーダンスが大きいときの発生パルス電圧の特性を示すもの である。

図 4 に, 表 1 の回路パラメータ(3)の条件, すなわち $C=4 \mathrm{nF}$ (充電電圧 $V_{\mathrm{C} 0}=-12 \mathrm{kV}$ ), $L=12.6 \mu \mathrm{H}$, 酸素濃度 $20 \%$ で流量 2 $\mathrm{L} / \mathrm{min}$ の場合のコンデンサ電圧 $V_{\mathrm{C}}$, SOS に流れる電流 $I_{0}$, リアクタ印加電圧 $V_{\text {out }}$, リアクタ電流 $I_{\mathrm{load}}$ の波形を示す。ま た，一次コンデンサのエネルギー $E_{\mathrm{C}}$, インダクタンスのエ ネルギー $E_{\mathrm{L}}$, リアクタでの消費エネルギー $E_{\mathrm{load}}$, 半導体開放 スイッチ SOS での損失エネルギー $E_{\mathrm{SOS}}$, 全エネルギー $E_{\mathrm{total}}$ を併せて示す。パルス電圧発生に伴いパルス電流が流れる が，電流立ち上がり部にこぶ状の波形が現れ，その後，主 パルスヘ至る。このこぶ状の電流は, リアクタの静電容量 に対する充電電流(16)であり，ピーク電流はストリーマ放電 によるものである。電流ピーク後, 電流がなだらかに減衰 する波形となっている。これは，グロー放電のフェーズに 相当する ${ }^{(14)(17)}$ 。大気圧で生成されたグロー放電の電子温度 は約 $1.3 \mathrm{eV}$ と低い(18)(19)。したがって，図 4 の $E_{\mathrm{load}}$ の電流ピ 一ク以降の増加分は, 電子エネルギーの比較的低いプラズ マ部を示す。本報告での誘導性エネルギー蓄積方式のパル スパワー電源は，一次コンデンサに蓄えたエネルギーを二 次インダクタに転送して電流を流し，その電流を SOS で遮 断してパルス電圧を発生させる方式をとっている。図 4 よ り，コンデンサに蓄えたエネルギーは，一旦インダクタに 移った後, 再度コンデンサに戻り, その後, 負荷へ転送さ れることがわかる。この過程でエネルギーの一部は回路損 失として失われ，放電後の $E_{\text {total }}$ は初期の $85 \%$ 程度に低下し ていることがわかる。回路パラメータ(3)の設定では，まだ コンデンサにエネルギーが残っている状態で電流の遮断が

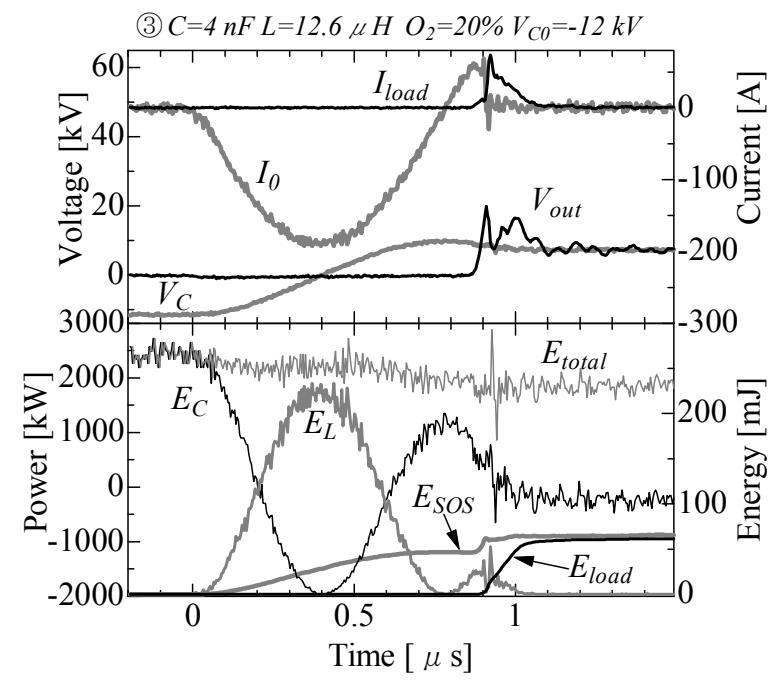

図 4 オゾン生成実験時の電圧, 電流およびエネルギー 推移波形 $\left(C=4 \mathrm{nF}, L=12.6 \mu \mathrm{H}\right.$ and $\left.V_{\mathrm{C} 0}=-12 \mathrm{kV}\right)$

Fig. 4. Waveforms of voltage, current and energy transfer from primary energy storage capacitor to discharge at $C=4 \mathrm{nF}$, $L=12.6 \mu \mathrm{H}$ and $V_{\mathrm{C} 0}=-12 \mathrm{kV}$.

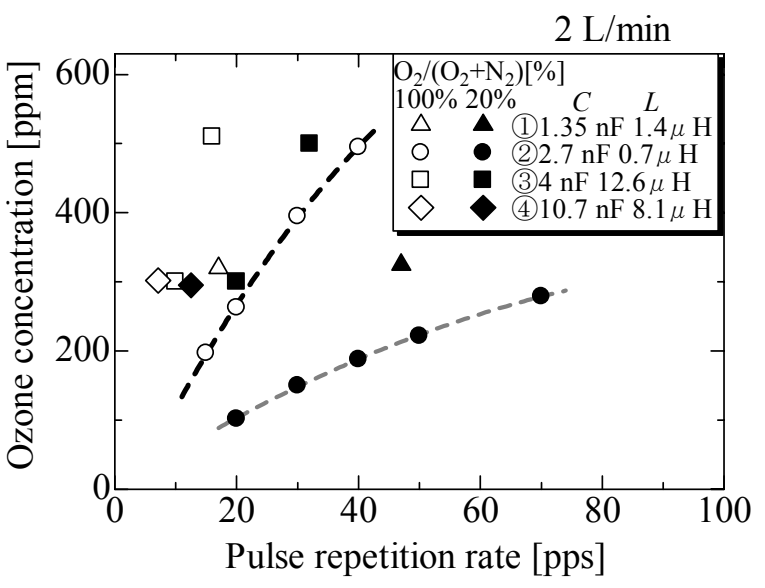

図 5 酸素濃度 $100 \%$ おび $20 \%$ におるパルス電圧の 繰返し周波数に対するオゾン生成濃度

Fig. 5. Ozone concentration as a function of a pulse repetition rate for $\mathrm{O}_{2} 100 \%$ and $20 \%$ conditions.

起こるため, 初期のエネルギー $\left(E_{\mathrm{C}}\right.$ の初期值 $)$ の約 $23 \%\left(E_{\mathrm{load}}\right.$ の最大值）しかリアクタへ転送されていないこともわかる。 エネルギー転送効率を高めるには, 回路パラメータの適切 な選定が必要になる ${ }^{(18)(19) 。 ~}$

〈3·2〉 オゾン生成効率 図 5 に, 表 1 の回路パラメ ータ(1)〜(4)について, 酸素濃度 100\%および酸素濃度 20\%(窒 素 $80 \%$ ）におけるパルス電圧の繰返し周波数とオゾン生成 濃度の関係を示す。図 5 よりオゾン生成濃度はパルス電圧 の繰返し周波数に比例して増加していることがわかる。

図 6 に, リアクタでの消費エネルギーとオゾン生成濃度 の関係を示す。ここで, リアクタでの消費エネルギー $U[\mathrm{~J} / \mathrm{L}]$ 


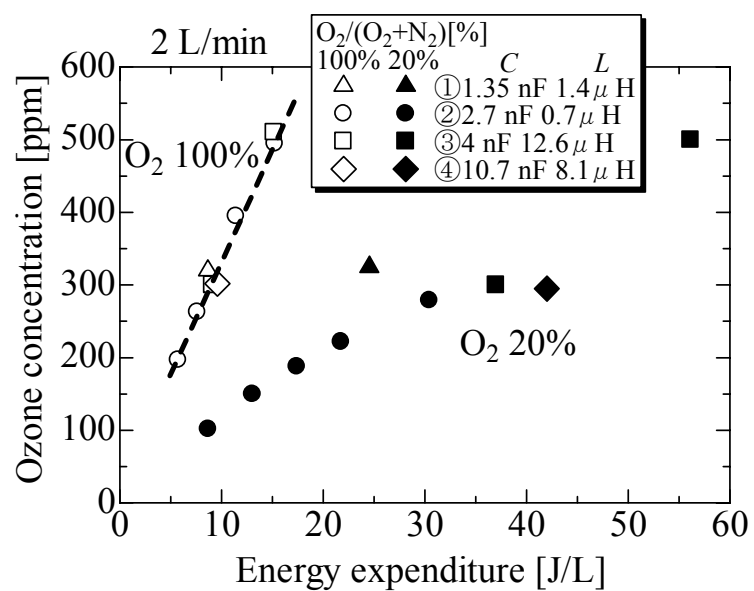

図 6 酸素濃度 $100 \%$ よび $20 \%$ におけるリアクタでの 消費エネルギーに対するオゾン生成濃度

Fig. 6. Ozone concentration as a function of energy expenditure for $\mathrm{O}_{2} 100 \%$ and $20 \%$ conditions.

は, リアクタでの消費電力 $P[\mathrm{~W}]$ とガス流量 $q[\mathrm{~L} / \mathrm{min}]$ と すると，下式で求められる。

$$
\begin{aligned}
& U=\frac{60 P}{q} \quad[\mathrm{~J} / \mathrm{L}] \\
& P=E_{l d} \cdot f \quad[\mathrm{~W}]
\end{aligned}
$$

ただし， $E_{l d}$ は 1 パルス当たりの消費エネルギー $[\mathrm{J}], f$ は繰 り返し周波数 $[\mathrm{pps}]$ を示している。また， $E_{l d}$ は以下の式で 求めた。

$$
E_{l d}=\int{ }^{t_{\text {lioad }}=0+}{ }_{t_{v_{\text {out }}=0-}} v_{\text {out }} \cdot i_{\text {load }} d t \quad[\mathrm{~J}]
$$

ここで， $v_{\text {out }}$ はリアクタに印加されるパルス電圧， $i_{\text {load }}$ はリ アクタに流れる電流である。 $E_{l d}$ は， $v_{\text {out }}$ が立上る直前 $\left(\left.t\right|_{v_{\text {out }}=0-}\right)$ から $i_{\text {load }}$ がピークを経て減衰しゼロになった直後 $\left(\left.t\right|_{i_{\text {load }}=0+}\right)$ までの電力 $v_{\text {out }} \cdot i_{\text {load }}$ を時間積分したものである。 図 6 より，オゾン生成濃度はリアクタでの消費エネルギー に比例して増加していることがわかる。酸素濃度 $100 \%$ の場 合には，リアクタでの消費エネルギー当たりのオン゙ン生成 濃度は回路条件によらずにほぼ一定になっているが，酸素 濃度 $20 \%$ の場合にはコンデンサ容量 $C$ が大きい方がリアク タでの消費エネルギー当たりのオゾン生成濃度が少なくな っている。

図 7 に, オゾン生成濃度とオゾン生成効率の関係を示す。 オゾン生成効率は, 下式により求めた。

$$
\eta=\frac{60 \cdot q \cdot\left[\mathrm{O}_{3}\right] \cdot M}{N \cdot P} \times 10^{-3} \quad[\mathrm{~g} / \mathrm{kWh}]
$$

ここで, $\left[\mathrm{O}_{3}\right]$ はオゾン生成濃度 $[\mathrm{ppm}], M$ はオゾンの分子量, $q$ はガス流量 $[\mathrm{L} / \mathrm{min}], N$ は $1 \mathrm{~mol}$ 当たりのガス体積 $[\mathrm{L}], P$ はリアクタでの消費電力 $[\mathrm{W}]$ を示している。図 7 より酸素 濃度 $100 \%$ の場合にはオゾン生成効率は $240 \mathrm{~g} / \mathrm{kWh}$ 程度とな り，酸素濃度 $20 \%$ の場合には 50〜 $100 \mathrm{~g} / \mathrm{kWh}$ 程度で，コン デンサの容量 $C$ の小さい条件の方がオゾン生成効率は高く なっていることがわかる。これはコンデンサの容量 $C$ の小

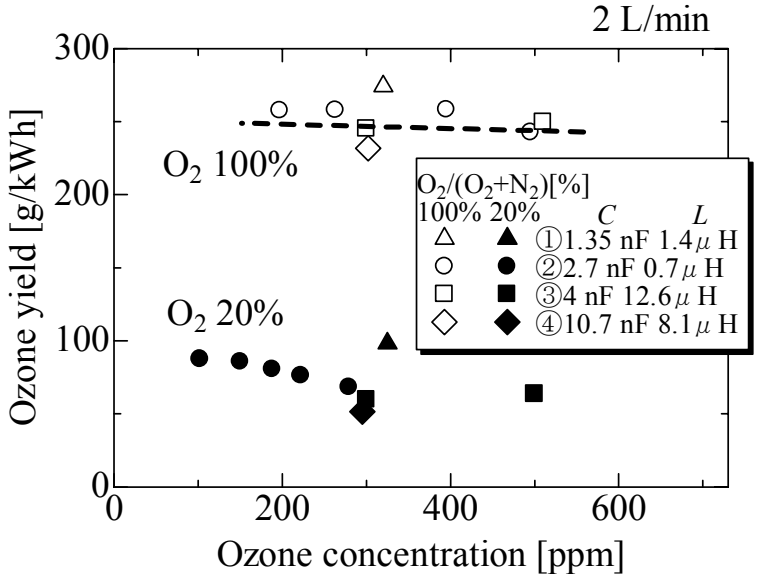

図 7 酸素濃度 100\%および 20\%におけるオゾン 生成濃度に対するオゾン生成効率

Fig. 7. Ozone yield as a function of ozone concentration for $\mathrm{O}_{2} 100 \%$ and $20 \%$ conditions.

さい方がグロー放電によるエネルギー消費が少ないため, $C$ が大きい条件の場合よりオゾン生成が効率的に行なわれる ためである ${ }^{(18)}$ 。ストリーマが進展し対向電極に到達した後 は, リアクタ内はストリーマ先端付近に比べて電子温度は 数 $\mathrm{eV}$ 程度と電子エネルギーの低いプラズマで満たされる ため, ラジカルの生成効率は減少する(20)。また, コンデン サ容量 $C$ を増すと, 放電時間も長くなり, プラズマが加熱 されるため, アーク放電へ転移しやすくなる ${ }^{(21)}$ 。すなわち, デンサの容量 $C$ が大きくなり, 順方向励起時間 $t_{\mathrm{f}}$ が長くな る場合，逆方向に電流が流れ遮断するまでの時間（SOS の 自己回復時間の定格值 $100 \mathrm{~ns}$ に遮断時間を加えた時間) が $t_{\mathrm{f}}$ の $1 / 2$ より小さくなる。この場合には, 図 4 に示すように SOS による電流遮断時にコンデンサ C に電荷が多く残留し, この残留電荷がグロー放電のエネルギー供給源になるた め, リアクタの放電条件によってはグロー放電やアーク放 電に移行するようになる。

図 8 に, 表 1 の(1)よび(3)の条件におけるオゾン生成効 率の酸素濃度の依存性を示す。オゾン生成濃度一定（ここ では $300 \mathrm{ppm}$ ）とした場合の効率を求めるために, パルスの 繰返し周波数を 16〜73 pps 程度に調整した。酸素濃度の高 い領域では, オゾン生成効率は, コンデンサ容量 $C$ に依存 せず $240 \mathrm{~g} / \mathrm{kWh}$ 程度になっている。しかしながら, 酸素濃 度が低下寸るに伴い, コンデンサ容量 $C$ の大きい(3)の条件 のオゾン生成効率が, $C$ が小さい(1)の条件より低くなってい る。これは, 前述のように, コンデンサ容量 $C$ が大きい場 合，グロー放電によるエネルギー消費が多くなるため， $C$ が小さい条件の場合よりオゾン生成が効率的に行なわれな くなるからである(18)。図 8 に, 酸素濃度による誘電体バリ ア放電（図中 DBD と表記）によるオゾン生成効率の特性を 併記する。酸素濃度の高い領域では, パルス放電による才 ゾン生成効率は，誘電体バリア放電に対し高くなっている。 一方, 酸素濃度の低い領域においては, コンデンサ容量 $C$ 


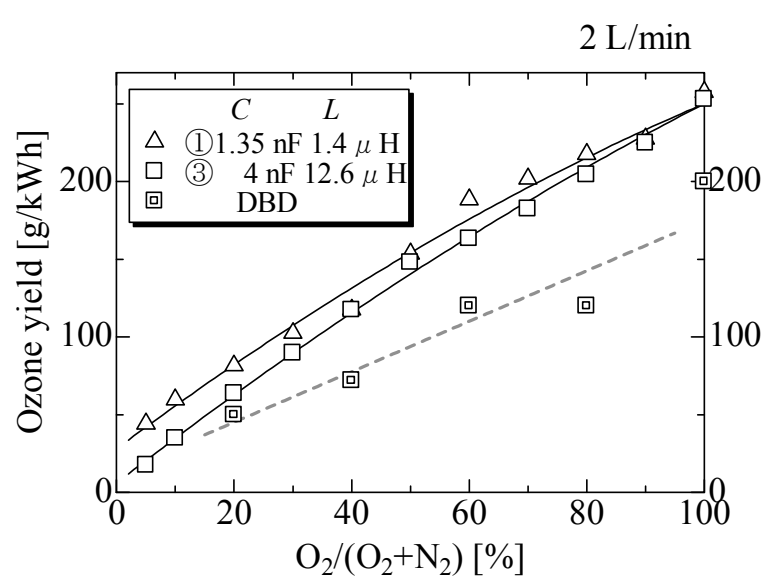

図 8 回路パラメータ(1)および(3)と誘電体バリア放電 (DBD) におけるオゾン生成効率の酸素濃度依存性

Fig. 8. Ozone yield as a function of ozone concentration for conditions (1),(3) and DBD.

が小さい(1)の条件では高い効率を示すが, $C$ が大きい(3)の条 件ではグロー放電発生の影響で，誘電体バリア放電と同程 度の効率になっていることがわかる。空気原料を用いた誘 電体バリア放電において， $\mathrm{N}_{2}, \mathrm{O}_{2}$ への電子エネルギー配分 は，換算電界 $100 \mathrm{Td}$ 以上ではガスの分圧に応じて均等に配 分される(22)(23)。このため, 酸素経由反応だけを考えると才 ゾン生成効率が酸素濃度に比例する。しかし, 一般に酸素 経由反応以外に以下のような窒素経由反応も進行する。

$$
\begin{aligned}
& \mathrm{N}_{2} \stackrel{e}{\longrightarrow} \mathrm{N}_{2}^{*} \rightarrow 2 \mathrm{~N} \\
& \mathrm{~N}+\mathrm{O}_{2} \rightarrow 2 \mathrm{O}+\mathrm{N} \\
& \mathrm{N}_{2}^{*}+\mathrm{O}_{2} \rightarrow \mathrm{O}_{2}^{*}+\mathrm{N}_{2}
\end{aligned}
$$

上記の反応により, 酸素経由反応のみの場合より大きなオ ゾン生成効率が得られる(22)(23)。図 8 より, パルス放電の場 合でもコンデンサ容量 $C$ が小さい条件(1)では, DBD 放電の 場合のように窒素経由反応の影響が現れているが，コンデ ンサ容量 $C$ が大きくグロー放電の発生する条件(3)では, 窒 素経由反応の影響を打ち消してしまうほどに，グロー放電 によるオゾン生成効率の低下が生じていることがわかる。

\section{4. まとめ}

半導体開放スイッチを用いたパルスパワー電源を用い, 酸素窒素混合ガス原料の酸素濃度を変化させてオゾン生成 効率を調查した結果，以下のことが明らかになった。

酸素原料でのオゾン生成効率は, 順方向励起時間によら ずに $240 \mathrm{~g} / \mathrm{kWh}$ 程度になる。酸素濃度が低下するに伴い才 ゾン生成効率は低下していくが, 順方向励起時間が長くグ ロー放電が発生する条件の方が，短い条件より低くなる。

一方, 誘電体バリア放電によるオゾン生成効率の特性と比 較すると, 酸素濃度の高い領域では, パルス放電によるオ ゾン生成効率は, 誘電体バリア放電に対しオゾン生成効率 は高い。また, 酸素濃度の低い領域においても, 順方向励
起時間の短い条件では高い効率を示すが, 順方向励起時間 が長くグロー放電が発生する条件では誘電体バリア放電と 同程度の効率となる。なお, グロー放電が発生しない順方 向励起時間が短い条件の場合, 酸素濃度低下に比例するほ どにはオゾン生成効率は低下しないが，これは酸素経由反 応以外に窒素経由反応の影響を現す誘電体バリア放電と同 様の傾向を示すものである。

最後に, 本研究を行うにあたり, 貴重なアドバイスを頂 いた徳島大学の下村直行先生, 実験に御協力を頂いた本学 佐藤淳弥氏, 佐藤大樹氏, 畑中友貴氏, 内藤潤氏に深く感 謝致します。

(平成 20 年 7 月 15 日受付, 平成 21 年 2 月 3 日再受付)

\section{文献}

（1）杉光英俊 : オゾンの基礎と応用，はしがき pp. i - ii，光琳 (1996)

(2) M. Shimizu, T. Sato, S. Kato, S. Mukaigawa, K. Takaki, and T. Fujiwara : "Improvement of Dielectric Barrier Discharge Plasma Reactor for Ozone Generation by Electrode Shape", IEEJ Trans. FM, Vol.125, No.6, pp.501-507 (2005-6) (in Japanese)

清水雅樹・佐藤 徹・加藤昭二・向川政治・高木浩一・藤原民也 : 「誘 電体バリア放電方式オゾナイザの電極形状による高効率化」, 電学論 A, 125, 6, pp.501-507 (2005-6)

(3) K. Takaki, S. Takahashi, S. Mukaigawa, T. Fujiwara, K. Sugawara, and T. sugawara : "Influence of Pellet Shape on Performance of Packed Bed Non-thermal Plasma Reactor", 2007 Japan-Korea Joint Symposium on Electrical Discharge and High Voltage Engineering, No.17B-a9, pp.199-202 (2007)

(4) パルスパワー放電とその高度利用技術調査専門委員会:「パルスパワ 一放電の物理とその高度応用研究の動向」, 電気学会技術報告, No.793, pp.23-24 (2000)

(5) H. Winands : Efficient Streamer Plasma Generation, Ph.D. thesis, Technische Universiteit Eindhoven (2007)

(6) H. Akiyama, Y. Miyahara, J. Samaranayake, and S. Katsuki : "Ozonizer Using Pulsed Power", J. Society of Plasma Science and Nuclear Fusion Research, Vol.74, No.10, pp.1139-1143 (1998-10) (in Japanese) 秋山秀典・宮原泰行・J. Samaranayake・勝木 淳：「パルスパワーを 用いたオゾナイザ」，プラズマ・核融合学誌，74，10，pp.1139-1143 (1998-10)

( 7 ) W. J. M. Samaranayake, Y. Miyahara, T. Namihira, S. Katsuki, R. Hackam, and H. Akiyama : "Ozone Generation in Dry Air Using Pulsed Discharges With and Without a solid Dielectric Layer", IEEE Trans. Dielect. Elect. Insulation, Vol.8, No.4, pp.687-697 (2001-8)

(8) I. V. Grekhov, S. V. Korotkov, A. L. Stepaniants, D. V. Khristyuk, V. B. Voronkov, and Y. V. Aristov : "High-Power Semiconductor-Based Nano and Subnanosecond Pulse Generator With a Low Delay Time", IEEE Trans. Plasma Sci., Vol.33, No.4, pp.1240-1244 (2005-8)

(9) T. Sasaki, S. Kato, S. Mukaigawa, K. Takaki, and T. Fujiwara : "Pulsed Power Generation using SOS diodes and application to exhaust gas treatment", J. IEEDJ, Vol.45, pp.51-54 (2002-12) (in Japanese) 佐々木崇・加藤昭二 ・向川政治・高木浩一・藤原民也 : 「SOS ダイオ ードを用いたパルスパワーの発生と排ガス処理への応用」, 放電研 究, 45, 別冊 2, pp.51-54 (2002-12)

(10) T. Go, N. Yamazaki, J. Sato, S. Mukaigawa, K. Takaki, and T. Fujiwara : "Ozone generation by Inductive Storage Energy System Pulsed Power Generator", 2007 Japan-Korea Joint Symposium on Electrical Discharge and High Voltage Engineering, No.17B-a1, pp.165-168 (2007)

(11) T. Namihira, T. Sakugawa, S. Katsuki, and N. Akiyama : "Pulsed Power Generator with Inductive-Energy Storage Using Semiconductor Opening Switch", J. Plasma Fusion Res., Vol.81, No.5, pp.355-358 (2005) (in Japanese)

浪平隆男・佐久川貴志・勝木 淳・秋山秀典: 「SOS ダイオードによ る誘導性エネルギー蓄積型パルス電源」, プラズマ・核融合学誌, 81, 5, pp.355-358 (2005) 
（12）郷 冨夫・兼沢京輔・向川政治・高木浩一・藤原民也：「SOS ダイオ 一ドを用いたパルスパワー電源の基礎特性」, 応用物理学会東北支部 第 61 回学術講演会講演予稿集, pp.208-209 (2006)

(13) 長ギャップ放電における空間電荷効果調査専門委員会:「長ギャッブ 放電の特性と理論の進歩」, 電気学会技術報告 (II 部), No.289, p.13 (1988)

(14) K. Takaki, M. Hosokawa, T. Sasaki, S. Mukaigawa, and T. Fujiwara : "Production of atmospheric-pressure glow discharge in nitrogen using needle-electrode", Appl. Phys. Lett., Vol.86, No.15, pp.151501-1-151501-3 (2003)

(15) 菅井秀郎：プラズマエレクトロニクス, pp.93-94, オーム社 (2000)

(16) R. Ono and T. Oda : "Measurement of OH Radicals in Pulsed Corona and Pulsed Dielectric Barrier Discharge", IEEJ Trans. FM, Vol.123, No.9, pp.920-925 (2003-9) (in Japanese)

小野 亮・小田哲治 :「パルスコロナおよびパルスバリア放電下での OH ラジカルの測定」, 電学論 A, 123, 9, pp.920-925 (2003-9)

(17) S. Sawada, K. Kanesawa, S. Mukaigawa, K. Takaki, T. Fujiwara, and T. Sasaki : "Influence of Streamer-to-Glow Transition in NOx Removal Using Pulsed Power Generator with SOS Diodes", IEEJ Trans. FM, Vol.127, No.4, pp.165-170 (2007-4) (in Japanese)

澤田定秀・兼沢京輔・向川政治・高木浩一・藤原民也・佐々木崇:「SOS ダイオードを用いたパルスパワー電源による NOx 除去におけるス トリーマーグロー転移の影響」, 電学論 A, 127, 4, pp.165-170 (2007-4)

(18) K. Takaki, K. Kanesawa, S. Mukaigawa, T. Fujiwara, and T. Go : “ Energy Efficiency of Corona Discharge Reactor Driven by Inductive Energy Storage System Pulsed Power Generator", IEEE Trans. Dielct. Elect. Insulation, Vol.14, No.4, pp.834-845 (2007)

(19) K. Takaki, H. Kirihara, C. Noda, S. Mukaigawa, and T. Fujiwara "Production of an Atmospheric-Pressure Glow Discharge Using an Inductive Energy Storage Pulsed Power Generator", Plasma Processes \& Polymers, Vol.3, pp.734-742 (2006)

(20) T. Namihira, S. Tsukamoto, D. Wang, S. Katsuki, R. Hackam, H. Akiyama, Y. Uchida, and M. Koike : "Improvement of $\mathrm{NO}_{\mathrm{X}}$ Removal Efficiency Using Short-Width Pulsed Power", IEEE Trans. Plasma Sci., Vol.28, No.2, pp.434-443 (2000-4)

(21) Investigation R\&D committee on fundamental technologies of arc and glow discharges : "Fundamental technologies of arc and glow discharge-investigations on recent technologies over whole fields of these discharges", IEEJ Abstract Contents of Technical Report No.1066, pp.12-13 (2006-9) (in Japanese)

アーク・グロー放電現象基礎技術調査専門委員会 :「アーク・グロー 放電の基礎技術」，電気学会技術報告, No.1066, pp.12-13 (2006-9)

(22) 岡村 一・小駒益弘・岡崎幸子：「微量 $\mathrm{SF}_{6}$ 添加によるオゾナイザ効 率向上とその機構」, 電気学会放電研資, ED-85-26, pp.91-100 (1985)

(23) B. Eliasson, U. Kogelschatz, and P. Baessler : "Dissociation of $\mathrm{O}_{2}$ in $\mathrm{N}_{2} / \mathrm{O}_{2}$ mixtures", J. Phys. B: At. Mol. Phys., Vol.17, pp.L797-L801 (1984)

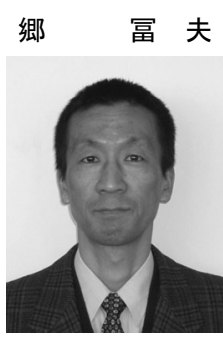

（正員） 1954 年 8 月 2 日生。1975 年 3 月釧路 工業高等専門学校卒業。同年 4 月（株）東芝入 社。浜川崎事業所, 府中事業所にて真空遮断器, スイッチギヤの開発業務に従事。2006 年 1 月よ り一関高専電気情報工学科教授。

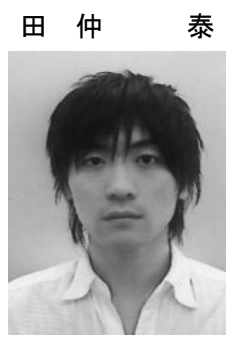

（非会員） 1985 年 9 月 12 日生。 2008 年 3 月岩 手大学工学部電気電子工学科卒業。同年 4 月同 大学大学院工学研究科前期博士課程電気電子 工学専攻入学, 現在に至る。主として, パルス パワーの発生とその応用に関する研究に従事。

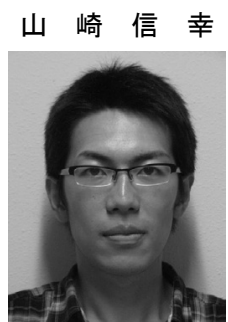

（学生員） 1984 年 8 月 15 日生。 2007 年 3 月岩 手大学工学部電気電子工学科卒業。同年 4 月同 大学大学院工学研究科前期博士課程電気電子 工学専攻入学, 現在に至る。主として, パルス パワーの発生とその応用に関する研究に従事。

向 川 政 治

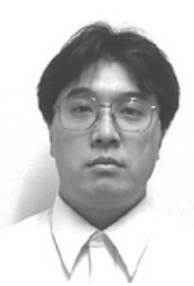

高 木 浩一

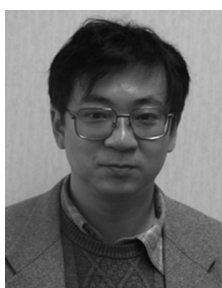

藤 原 民 也

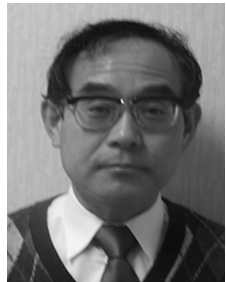

(正員) 1970 年 9 月 15 日生。1998 年 3 月広 島大学大学院博士課程後期修了。同年 8 月広島 大学ナノデバイス・システム研究センター講師 (研究機関研究員)。2001 年 4 月岩手大学工学部 電気電子工学科助手, 現在に至る。理学博士。 応用物理学会, 日本物理学会会員。

\section{（正員） 1963 年 10 月 16 日生。1988 年 3 月熊 本大学大学院修士課程修了。1989 年 4 月大分高 専電気工学科助手, 1996 年 4 月岩手大学工学部 電気電子工学科助手, 2001 年 3 月同助教授, 現 在に至る。2000 年 10 月〜2001 年 9 月マクマス タ一大学客員研究員。工学博士。応用物理学会, 静電気学会, プラズマ・核融合学会, 放電学会, IEEE 会員。}

（正員） 1947 年 4 月 17 日生。1973 年 3 月東 北大学大学院修士課程修了。同年 4 月一関高専 電気電子工学科助手。1 1975 年 4 月岩手大学工学 部電気電子工学科助手, 講師, 助教授を経て, 1994 年 2 月同教授。 1987 年 3 月 1988 年 3 月 マサチューセッツ工科大学客員研究員。工学博 士。応用物理, プラズマ・核融合学会会員。 